\title{
Abiraterone Acetate Withdrawal Syndrome: Does It Exist?
}

\author{
Hélène Gauthier $^{\mathrm{a}} \quad$ Guilhem Bousquet $^{\mathrm{a}-\mathrm{c}}$ \\ Damien Pouessel $^{\mathrm{a}}$ Stéphane Culine ${ }^{\mathrm{a}, \mathrm{b}}$

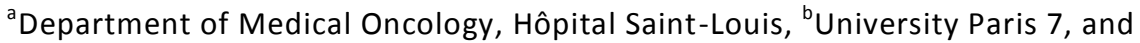 \\ 'Inserm U728, Paris, France
}

\section{Key Words}

Prostate cancer - Castrate-resistant prostate cancer - Abiraterone - Withdrawal syndrome

\begin{abstract}
In 2011 abiraterone acetate (AA) was approved for the treatment of castrate-resistant metastatic prostate cancer patients who have failed docetaxel chemotherapy. We report the case of a patient who experienced a confirmed PSA decrease of $\geq 50 \%$ after stopping AA, mimicking an antiandrogen withdrawal syndrome.
\end{abstract}

\section{Introduction}

Initially described after treatment with flutamide, responses to withdrawal of hormonal therapies in prostate cancer patients have been documented after cessation of other antiandrogens - such as nilutamide, bicalutamide, or cyproterone acetate - and of megestrol acetate, diethylstilbestrol or estramustine. In the Southwest Oncology Group Trial 9426, 21\% of 210 patients had confirmed PSA decreases of $\geq 50 \%$ after treatment with nonsteroidal antiandrogens with a median progression-free survival of 3 months [1]. It has been proposed that withdrawal responses could result from mutations in the androgen receptor (AR). Transfection experiments revealed that AR point mutations in the hormone-binding domain allow activation by ligands other than dihydrotestosterone. Mutated AR from clinical samples was shown to be activated by progesterone, estradiol, adrenal androgens, hydrocortisone or hydroxyflutamide [2]. However, a prospective study failed to demonstrate a clear association between detectability of AR mutations and antiandrogen withdrawal responses [3].

An improvement in overall survival has been reported with abiraterone acetate (AA), a selective inhibitor of cytochrome P450c17 (CYP17), in castrate-resistant prostate cancer patients who have failed docetaxel chemotherapy [4]. The addition of 
low-dose corticoids to AA is mandatory in daily practice since the combination has been shown to minimize the syndrome of secondary mineralocorticoid excess related to CYP17 inhibition [5]. Here, we report the case of a patient who had a confirmed PSA decrease of $\geq 50 \%$ after stopping AA, mimicking a withdrawal syndrome.

\section{Case Report}

A 60-year-old patient was diagnosed with a prostate adenocarcinoma (Gleason score 8, 4+4) with synchronous bone metastases in April 2007. He successively received an LHRH agonist, a combined androgen blockade with LHRH agonist and bicalutamide, without subsequent response to bicalutamide withdrawal, docetaxel (10 cycles), then mitoxantrone (3 cycles) and diethylstilbestrol. In April 2011, serum PSA increased to $77 \mathrm{ng} / \mathrm{ml}$ without bone pain. AA was started at the standard dose of $1,000 \mathrm{mg}$ daily in combination with prednisone (5 mg twice daily). PSA slightly decreased to a nadir of $68 \mathrm{ng} / \mathrm{ml}$ one month after the start of treatment. In parallel, a metabolic partial response according to consensus criteria on 18-fluorodeoxyglucose positron emission tomography (PET) and choline PET $(\triangle \mathrm{SUVmax}=-37 \%)$ was observed [6]. However, AA and prednisone were stopped in August 2011 because of back pain related to vertebral metastases and concomitant PSA progression (PSA $128 \mathrm{ng} / \mathrm{ml}$ ). One month later, a confirmed PSA decrease to a nadir of $62 \mathrm{ng} / \mathrm{ml}$ occurred, defining a partial biological response according to standard criteria, with a concomitant improvement in back pain [7]. Three months after stopping AA, a biological and clinical progression occurred (fig. 1).

\section{Discussion}

To the best of our knowledge, this is the first case ever reported of a withdrawal response with AA. Currently proposed mechanisms of resistance to AA include ligandless activation of AR by constitutively active variants lacking the ligand-binding domain, cross-talk with relative signaling pathways and/or activation of amplified or promiscuous AR by nonandrogenic ligands such as corticosterone or other steroids [8]. Following the latter hypothesis, the withdrawal response observed in the present case could be related rather to prednisone than to AA itself as it was stopped at the same time. Further reports are required to confirm such a phenomenon.

\section{Disclosure Statement}

The authors have no conflict of interest to declare. 


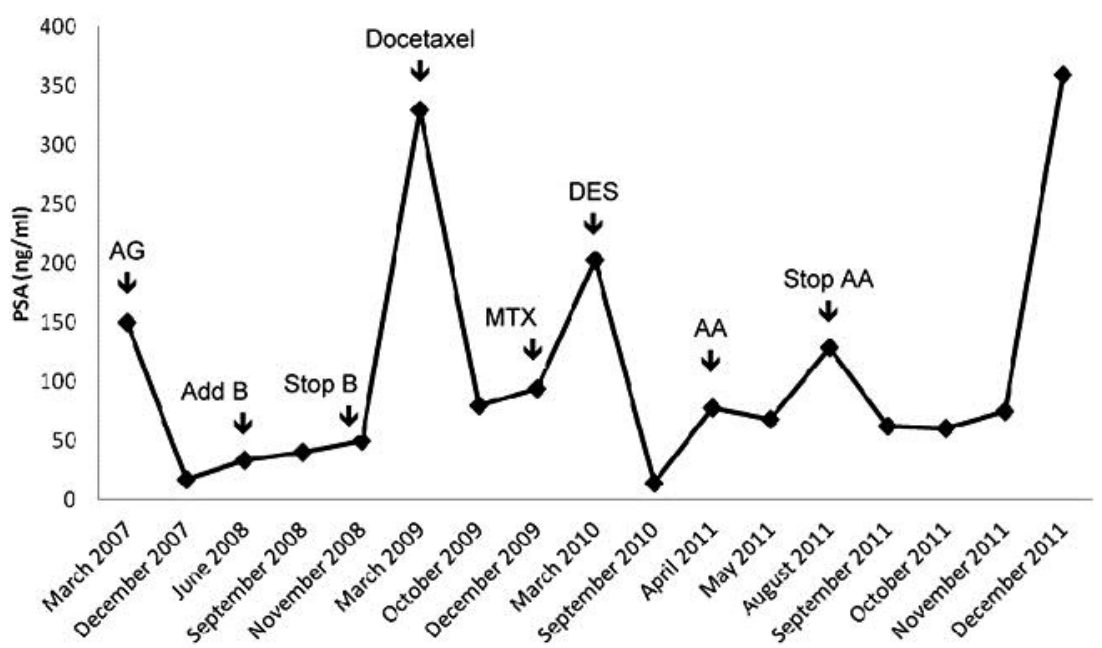

Fig. 1. PSA over time. $\mathrm{AG}=\mathrm{LHRH}$ agonist; $\mathrm{B}=$ bicalutamide; $\mathrm{MTX}=$ mitoxantrone; $\mathrm{DES}=$ diethylstilbestrol.

\section{References}

-1 Sartor AO, Tangen CM, Hussain MHA, Eisenburger MA, Parab M, Fontana JA, Chapman RA, Mills GM, Raghavan D, Crawford ED: Antiandrogen withdrawal in castrate-refractory prostate cancer: a Southwest Oncology Group trial (SWOG 9426). Cancer 2008;112:2393-2400.

$\checkmark 2$ Gelmann EP: Molecular biology of the androgen receptor. J Clin Oncol 2002;20:3001-3015.

-3 Taplin ME, Rajeshkumar B, Halabi S, Werner CP, Woda BA, Picus J, Stadler W, Hayes DF, Kantoff PW, Vogelzang NJ, Small EJ: Androgen receptor mutations in androgen-independent prostate cancer: Cancer and Leukemia Group B study 9663. J Clin Oncol 2003;21:2673-2678.

-4 de Bono JS, Logothetis CJ, Molina A, Fizazi K, North S, Chu L, Chi KN, Jones RJ, Goodman OB Jr, Saad F, Staffurth JN, Mainwaring P, Harland S, Flaig TW, Hutson TE, Cheng T, Patterson H, Hainsworth JD, Ryan CJ, Sternberg CN, Ellard SL, Fléchon A, Saleh M, Scholz M, Efstathiou E, Zivi A, Bianchini D, Loriot Y, Chieffo N, Kheoh T, Haqq CM, Scher HI: Abiraterone and increased survival in metastatic prostate cancer. N Engl J Med 2011;364:1995-2005.

-5 Attard G, Reid AHM, Yap TA, Raynaud F, Dowsett M, Settatree S, Barrett M, Parker C, Martins V, Folkerd E, Clark J, Cooper CS, Kaye SB, Dearnaley D, Lee G, de Bono JS: Phase I clinical trial of a selective inhibitor of CYP17, abiraterone acetate, confirms that castration-resistant prostate cancer commonly remains hormone driven. J Clin Oncol 2008;26:4563-4571.

-6 Young H, Baum R, Cremerius U, Herholz K, Hoekstra O, Lammertsma AA, Pruim J, Price P: Measurement of clinical and subclinical tumour response using [18F]-fluorodeoxyglucose and positron emission tomography: review and 1999 EORTC recommendations. European Organization for Research and Treatment of Cancer (EORTC) PET Study Group. Eur J Cancer 1999;35:1773-1782.

7 Scher HI, Halabi S, Tannock I, Morris M, Sternberg C, Carducci MA, Eisenberger MA, Higano C, Bubley GJ, Dreicer R, Petrylak D, Kantoff P, Basch E, Kelly WK, Figg WD, Small EJ, Beer TM, Wilding G, Martin A, Hussain M: Design and end points of clinical trials for patients with progressive prostate cancer and castrate levels of testosterone: recommendations of the Prostate Cancer Clinical Trials Working Group. J Clin Oncol 2008;26:1148-1159.

-8 Zhao XY, Malloy PJ, Krishnan AV, Swami S, Navone NM, Peehl DM, Feldman D: Glucocorticoids can promote androgen-independent growth of prostate cancer cells through a mutated androgen receptor. Nat Med 2000;6:703-706. 